\title{
ISLAM DEMOKRATIS PERSPEKTIF RACHID GHANNOUCHI
}

\author{
Muhammad Rusdi bin Muhammaddiah, Muhazir \\ Hukum Tata Negara, Fakultas Syariah, IAIN Langsa \\ Jl. Meurandeh, Kota Langsa, Prov. Aceh, 24411 \\ 'muhammadrusdi@iainlangsa.ac.id
}

\begin{abstract}
Rachid Ghannouchi is one of the foremost political Islamic figures in Tunisia. His various ideas and ideas are summarized in the political parties he has founded, his political movements clearly illustrate that the political style he promotes leads to Islamic values. The Ennahda party became the political mobilizer promoted by Rachid Ghannouchi. However, recently Rachid Ghannouchi has announced a new phase in his political style by carrying out the concept of Islamic Democracy (al-Islam al-Dimuqratiyah). The concept of democracy is actually strange in politics in Tunisia, so that the concept promoted by Rachid Ghannouchi is claimed to be part of the ideology of the Ikhwanul Muslimin party in Egypt. This paper examines the concept of democracy (al-Islam alDimuqratiyah) promoted by Rachid Ghannouchi in the political system and state. In contrast to other Muslim political figures who glorify the western democratic system, Rachid Ghannouchi combines western democracy and Islam, resulting in a different viewpoint and rejecting the view that Islam hinders democracy. There are at least two concepts of democracy that are carried, namely the concept of shura and hurriyah.
\end{abstract}

Keywords: Rachid al-Ghannouchi, Ennahda, Tunisia, Democratic Islam

Abstrak Rachid Ghannouchi merupakan salah satu tokoh politik Islam terkemuka di Tunisia. Berbagai ide dan gagasannya terangkum dalam Partai politik yang telah didirikannya, pergerakan politiknya secara jelas menggambarkan bahwa gaya politik yang diusungnya mengarah kepada nilai dan ajaran Islam. Partai Ennahda menjadi mobilisator politik yang diusung oleh Rachid Ghannouchi. Namun, baru-baru ini Rachid Ghannouchi telah mengumumkan fase baru dalam gaya politiknya dengan mengusung konsep Islam Demokrasi (al-Islam al-Dimuqratiyah). Konsep demokrasi sejatinya masing tabu dalam perpolitikan di Tunisia, sehingga konsep yang diusung oleh Rachid Ghannouchi diklaim merupakan bagian dari ideologi partai Ikhwanul Muslimin di Mesir.Tulisan ini mengkaji tentang konsep demokrasi (al-Islam al-Dimuqratiyah) yang diusung oleh Rachid Ghannouchi dalam sistem politik dan bernegara. Berbeda dengan tokoh-tokoh politik muslim lainya yang mengagungkan sistem demokrasi barat, Rachid Ghannouchi mengkombinasikan antara demokrasi barat dan Islam, sehingga menghasilkan sudut pandang yang berbeda dan menolak pandangan bahwa Islam menghambat demokrasi. Setidaknya ada dua konsep demokrasi yang diusung yaitu konsep shura dan hurriyah.

Katakund: Rachid al-Ghannouchi, Ennahda, Tunisia, Islam Demokratis 
Volume 16, Nomor 1, Januari - Juni 2021

\section{Pendahuluan}

Kebangkitan partai politik Islam setelah terjadinya al-Tsaurat al-Arabiyah ${ }^{1}$ yang berawal dari aksi bakar diri (self-immolation) yang dilakukan oleh Bouazizi di Tunisia, memberikan efek domino yang sangat besar ke wilayah-wilayah Arab lainnya. Tumbangnya rezim Ben Ali yang telah memerintah puluhan tahun di Tunisia dengan tangan besi tidak dapat dicegah. Aksi self-immolation yang dilakukan Bouazizi, segera mendapat perhatian luas. Tidak hanya media lokal dan nasional saja yang melakukan pemberitaan tersebut, tetapi berbagai media internasional juga meliput dan merekam dengan jelas peristiwa tersebut, yang selanjutnya diikuti oleh aksi demontrasi yang mengguncang rezim yang telah berkuasa secara otoriter selama puluhan tahun, tidak hanya di Tunisia, revolusi juga menyebar ke negaranegara Arab lainnya semisal Mesir, Libya, Suriah dan lainnya.

Rachid Ghannouchi adalah salah satu pemimpin politik paling terkemuka yang membawa perubahan dan mempengaruhi pemikiran sarjana muslim lain, khususnya dalam bidang politik. Sosok Ghannouchi sangat dikagumi dan dihormati dinegaranya (Tunisia) karena ia merupakan pendiri partai Ennahda. Sebuah partai yang berhaluan Islam dan berhasil memenangkan mayoritas kursi parlemen (61\%) pada pemilihan umum yang demokratis pada tahun 2011 setelah tumbangnya rezim otoriter Ben Ali yang telah memerintah lebih dari dua dekade.

Salah satu langkah politik yang dilakukan oleh Ghannouchi saat itu, dan mungkin tidak akan pernah terpikirkan oleh lawan politiknya adalah ketika ia membuat satu keputusan yang kontroversial, yaitu setelah berhasil menguasai mayoritas parlemen, Ghannouchi dan partainya Ennahda setuju untuk berbagi kekuasaan dengan partai Nida Tounis. Nida Tounis adalah partai nasional yang berhaluan sekuler. Diyakini, Alasan utamanya saat itu adalah semata-mata untuk menjaga stabilitas dan perdamaian di Tunisia, menghindari berbagai konfrontasi apapun yang sangat mungkin untuk terjadi, terutama antara kelompok sekularis dan kelompok Islamis. Ghannouchi rela berbagi kekuasaan dengan membentuk koalisi dalam parlemen dengan partai-partai yang notabene berlawanan arah haluan dari partai yang dipimpinnya. ${ }^{2}$ Disisi lain, pembagian kekuasaan antara partai Ennahda dan partai Nida Tounis dianggap sebagai 'kompromi' dan 'tawar-menawar' antara dua partai yang bertolak belakang dalam haluan tersebut. Terbukti, kedua partai tersebut tidak merubah ideologi pemikiran politiknya. Ennahda tetap bertahan dengan ideologi Islamnya, sementara Nida Tounis tetap dengan doktrin sekulernya.

\footnotetext{
${ }^{1}$ Sean Yom, "The Arab Spring: One Region, Several Puzzles, and Many Explanations," Government and Opposition, Vol. 50, No. 4, 2015, hlm. 15

${ }^{2}$ Elliott Abrams, Realism and Democracy: American Foreign Policy after the Arab Spring (New York: Cambridge University Press, 2017),hlm, 44
} 
Volume 16, Nomor 1, Januari - Juni 2021

Sebagai seorang pemimpin politik, Ghannouchi memiliki pemikiran politik tersendiri dalam membuat keputusan besar tersebut. Tunisia yang baru saja berada di awal-awal demokrasi, sangat perlu untuk menjaga stabilitas politik dalam negerinya. Sebagai akibat dari pendekatan politik yang dilakukan oleh Ghannouchi tersebut, Tunisia sekarang dianggap sebagai negara yang stabil dan damai dalam perpolitikan. Hal ini tentu berimbas kepada penguatan ekonomi negara tersebut dan menjadi 'pekerjaan rumah' yang utama setelah terjadinya al-Tsaurat al-Arabiyah (Arab Spring), dimana salah satu faktor terjadinya revolusi di negara tersebut adalah terpuruknya ekonomi dalam negeri selama kepemimpinan Presiden Ben Ali. Ghannouchi sendiri sering menyebut langkah politik yang diambilnya dengan istilah al-Islam al-Dimuqratiyah (Islam Demokratis). Langkah politik ini sendiri banyak diadopsi oleh partai-partai Islam didunia, sebut saja seperti Partai Keadilan Sejahtera (PKS) di Indonesia dan Partai Islam se-Malaysia (PAS) di Malaysia.

Indonesia sebagai negara yang mayoritas muslim tidak luput dari pemikiran politik Islam, pada awal kemerdekaan pergerakan politik berbasis Islam demokrasi telah tumbuh meskipun masih diperdebatkan antara kalangan tradisionalis dan modernis. Namun, mayoritas umat muslim Indonesia menerima demokrasi karena memandang adanya kesamaan nilai-nilai demokrasi dengan Islam. ${ }^{3}$

Penelitian yang mengkaji tentang Rachid Ghannouchi yaitu Maszlee Malik ${ }^{4}$ yang mengkaji pengaruh dan motivasi dari pengaruh politik yang diusung oleh Rachid Ghannouchi di Tunisia. Tulisan ini akan mengkaji lebih mendalam lagi tentang gaya dan konsep politik yang diusung oleh Rachid Ghannouchi yang dipandang tabu oleh masyarakat Tunisia, bahkan gaya domokrasi yang digagas oleh Rachid Ghannouchi berbeda dengan konsep demokrasi barat dengan memadukan teori demokrasi dalam Islam yang pada akhirnya menciptakan dinamika yang berbeda dalam perpolitikan di Tunisia.

\section{Metode Penelitian}

Tulisan ini merupakan penelitian pustaka (library research) ${ }^{5}$ dengan pendekatan kualitatif, ${ }^{6}$ penelitian pustaka dalam tulisan ini merupakan penelitian yang mencatat, membaca dan mengolah data yang ditemukan dari proses penelusuran, sedangkan pendekatan kualitatif digunakan untuk mendiskripsikan tokoh dan pola pemikiran yang digunakan oleh

\footnotetext{
${ }^{3}$ Kiki Muhamad Hakiki, "Islam dan Demokrasi: Pandangan Intelektual Muslim dan Penerapannya di Indonesia," Wawasan: Jurnal Ilmiah Agama dan Sosial Budaya, Vol. 1, No. 1, 2016, hlm 1-17.

${ }^{4}$ Maszlee Malik, "From Political Islam to Democrat Muslim: A Case Study of Rashid Ghannouchi's Influence on ABIM, IKRAM, AMANAH and DAP," Intellectual Discourse, Vol. 25. No, 1, 2017, hlm. 27.

${ }_{5}^{5}$ Mestika Zed, Metode Peneletian Kepustakaan (Jakarta: Yayasan Obor Indonesia, 2004), hlm, 3

6 Ajat Rukajat, Pendekatan Penelitian Kualitatif (Qualitative Research Approach) (Yogyakarta: Deepublish, 2018), hlm, 5
} 
Volume 16, Nomor 1, Januari - Juni 2021

Rachid Ghannouchi dalam mengintegrasikan antara demokrasi dan Islam serta aplikasinya di Tunisia. Dalam tulisan ini juga akan menganalisis pola integrasi antara demokrasi dan Islam yang ditawarkan oleh Rachid Ghannouchi serta pengeruhnya dalam perpolitikan di Tunisia.

\section{Pembahasan}

\section{A. Biografi Rachid Ghannouchi}

Rachid Ghannouchi lahir di el-Hamma, sebuah wilayah di Tunisia Selatan pada Juni 1941. Ghannouchi adalah salah satu diantara para pemikir muslim yang paling terkenal di dunia Arab saat ini. Beliau adalah seorang penulis, politisi, pendiri partai Ennahda, dan merupakan salah satu tokoh Islam paling terkemuka di Tunisia. Setelah lulus dari Universitas ez-Zitouna padah tahun 1962, Rachid Ghannouchi melanjutkan studinya di luar negeri. Ia melanjutkan pendidikannya ke Mesir dan memilih Universitas Kairo untuk belajar tentang pertanian. Namun, ketika itu ia dan mahasiswa Tunisia lainnya diberhentikan dari universitas tersebut, menyusul terjadinya ketegangan politik antara Presiden Habib Bourguiba (Tunisia) dengan Presiden Jamal Abdel Naser (Mesir). Setelah itu, Ghannouchi melanjutkan studinya ke Universitas Damaskus di Suriah. Disana Ghannouchi muda mendalami pengetahuannya tentang filsafat. Disanalah Ghannouchi memulai membentuk orientasi politiknya dengan bergabung dalam kegiatan-kegiatan politik.

Setelah menyelesaikan pendidikannya di Universitas Damaskus, Rachid Ghannouchi melanjutkan studinya di Sorbonne University di Paris. Setelah belajar disana selama setahun, Ghannouchi kembali ke Tunisia dan mendirikan sebuah organisasi yang bertujuan untuk melakukan reformasi di negara ini. Sebagai seorang tokoh yang agamais, ia juga mendirikan The Movement of Islamic Tendency (al-Harakah al-Islamiyah) pada tahun 1981, yang kemudian berganti nama menjadi Partai Ennahda. Dengan langkah ini, Ghannouchi bermaksud untuk memperjuangkan keragaman politik dan mempromosikan rekonstruksi ekonomi. Selama periode ini, ia menghadapi banyak penuntutan oleh rezim pemerintah. Rachid Ghannouchi bersama dengan pengikutnya, disiksa dan dipenjara hingga 11 tahun. Karena dukungan dan desakan dari kalangan aktivis politik dan masyarakat sipil, akhirnya Ghannouchi dan pengikutnya dibebaskan pada tahun 1984.

Pada tahun 1987, rezim pemerintah kembali menjebloskan Ghannouchi dan pengikutnya kedalam penjara. Ia dan pengikutnya dihukum menjadi buruh seumur hidup. Namun, lagi-lagi akibat desakan dari kalangan aktivis politik dan masyarakat, ia dan pengikutnya dibebaskan pada tahun 1988. Selanjutnya, pasca pemilihan umum yang dimenangkan oleh Presiden Zine El Abidine Ben Ali pada tahun 1989, Ghannouchi dan pengikutnya di ekstradisi ke aljazair dengan tuduhan ingin menggulingkan pemerintahan. Selanjutnya, pada tahun 1991 Ghannouchi pindah dari aljazair ke london, disana ia tinggal 
Volume 16, Nomor 1, Januari - Juni 2021

dan menghabiskan waktunya selama lebih dari dua dekade. Dalam pengasingannya di london, Ghannouchi menjadi sosok yang paling gencar mengkritik rezim pemerintahan Ben Ali di Tunisia. Akhirnya, Rachid Ghannouchi bisa kembali ke tanah airnya untuk pertama kalinya pada 30 januari 2011 setelah terjadinya al-Tsaurat al-Arabiyah (arab spring) di Tunisia. Kepemimpinan Rachid Ghannochi telah memberikan kontribusi pada pertumbuhan konsensus diantara partai-partai politik yang berbeda. Kesediaannya untuk bekerja dengan lawan politik, telah memberikan kemajuan yang signifikan pada kemajuan Tunisia dalam transisi demokrasi.

Ghannouchi secara global diakui sebagai salah satu 'pemimpin intelektual' dan ideolog Partai Ennahda Tunisia. Ia dianggap sebagai salah satu tokoh terkemuka dalam bidang pemikiran Islam kontemporer. Ide-idenya tentang isu-isu Islam dan modernitas, demokrasi dan sekularisme, hubungan antara Timur dan Barat, Hak Asasi Manusia dan masyarakat sipil, telah dikutip oleh para pemikir Islam, cendekiawan muslim, dan aktivis di seluruh dunia.

\section{B. Latar belakang pemikiran politik Ghannouchi}

Ghannouchi melalui Partainya Ennahda, berpegang secara teguh kepada konsep Maqasid al-Syari'ah yang telah diperkenalkan dan dikembangkan secara mendalam oleh Abu Ishaq al-Shatibi, salah satu ulama dari al-Maghrib al-'Arabi (wilayah Afrika Utara) dan penulis kitab besar, al-Muwafaqat. Teori-teori tentang maqasid kemudian diterjemahkan kedalam aplikasi modern oleh ulama besar Tunisia yaitu Tahir ibn 'Asyur. Menurut Maqasid al-Syari'ah, setiap tindakan, peraturan atau kebijakan yang dilakukan dan diadopsi oleh umat Islam harus sesuai dengan maksud tertinggi dari syari'ah. Hal itu dicontohkan dalam pelestarian dan promosi lima kualitas utama dalam kehidupan manusia, yaitu kehidupan dan kualitas hidup, agama, pikiran dan intelektual, kekayaan dan keturunan, selanjutnya beliau menambahkan tiga kualitas lagi yaitu al-Hurriyah (kebebasan), al-'Adalah (keadilan), dan alMusawah (kesetaraan). ${ }^{7}$ Berbagai keputusan yang dikeluarkan oleh Partai Ennahda, harus sejalan dengan visi tersebut. Untuk itu, pendekatan maqasid merupakan pendekatan partai yang dijalankan oleh Ennahda.

Berdasarkan pertimbangan inilah, Ennahda yang dinahkodai oleh Ghannouchi percaya bahwa pelestarian dan pemeliharaan kebebasan dan keadilan, harus menjadi prioritas tertinggi saat ini dan waktu mendatang. Ennahda juga percaya bahwa tanggung jawab itu tidak dapat diemban sendirian. Sebagai pemimpin sekaligus ideolog dari Ennahda, Ghannouchi sangat menganut pendekatan maqasid dalam keputusan apapun yang diambil partai. Ghannouchi selalu bersikeras bahwa Ennahda harus melayani Tunisia berdasarkan pada alasan kuat bahwa Tunisia adalah untuk semua warga Tunisia dan bukan hanya untuk

\footnotetext{
${ }^{7} \mathrm{Mu}$ ammad a - āhir Ibn- Asur, Treatise on Maqāșid Al-Shari ${ }^{i}$ ah (London: Internat. Inst. of Islamic Thought, 2006), hlm, 24
} 
Volume 16, Nomor 1, Januari - Juni 2021

muslim. Dalam mencapai itu, Ghannouchi memastikan bahwa Ennahda akan selalu berpegang teguh pada prinsip-prinsip kebebasan politik, kebebasan berbicara, kebebasan ide, serta semua nilai-nilai yang menjadikan Tunisia sebagai negara beradab. Idealnya, maqasid yang merupakan visi dari Ghannouchi dan Partainya Ennahda, menjunjung tinggi konsep Shura (musyawarah) dan Tasamuh (saling menghormati) dalam berpolitik ${ }^{8}$.

Ghannouchi menekankan bahwa pemahaman yang komprehensif tentang esensi Islam akan mengarah pada apresiasi dalam berdemokrasi. Demokrasi, dengan unsur Islam akan memberi manusia nilai yang lebih besar dari sekedar nilai politik dan sosial, yaitu nilai penghormatan kepada martabat manusia. Namun, tema sentral dalam konsep Ghannouchi adalah bahwa demokrasi harus sesuai dengan Islam. Dan bahwa umat Islam perlu memberi ruang besar kedalam pemikiran politik mereka. Jauh lebih penting, bahwa seorang muslim sejati adalah orang yang menganut nilai-nilai demokrasi. Karenanya, seorang muslim pada dasarnya adalah seorang demokrat. Demikian pula, Ghannouchi juga menekankan pada gagasan muwatanah (kewarganegaraan) untuk semua warga negara muslim. Ghannouchi bersikeras bahwa perbedaan antara muslim dan non-muslim dalam suatu negara tidak lagi berlaku di negara-negara modern. Setiap warga negara harus diperlakukan sama, dan harus menikmati hak dan tanggung jawab yang sama.

Dalam menjelaskan pendekatan Ennahda terhadap politik di Tunisia, Ghannouchi dalam banyak wawancara, menekankan bahwa inklusivitas, demokrasi dan keterbukaan adalah prinsip utama yang dipegang. Dia juga menolak dikaitkan dengan radikalisme, konservatisme, dan visi apapun untuk mendirikan negara teokratis di Tunisia'. Ia juga berkeyakinan bahwa pembagian kekuasaan dan pluralitas politik adalah model ideal untuk negara-negara muslim modern. Dalam membenarkan posisinya tentang pluralitas politik, Ghannouchi mengatakan bahwa itu sejalan dengan semangat Piagam Madinah yang diprakarsai oleh Nabi Muhammad Saw, ketika pertama kali tiba di Madinah untuk mendirikan negara Islam pertama. Dalam sejarah kita dapatkan, bahwa Negara Islam Madinah tidak hanya terdiri dari Muslimin dan orang-orang Madinah, tetapi juga orang-orang non-muslim dan non-madinah ${ }^{10}$. Beranjak dari pemikiran diatas, Ghannouchi berhasil menjauhkan dirinya dan partainya dari prinsip Islam konvensional yang berorientasi kepada pembentukan Negara Islam dengan penerapan syariat Islam.

Aspek penting lain dari pemikiran politik Ghannouchi, yang dikristalisasi dalam keputusan politik yang dibuat Ennahda, adalah 'inklusi politik' dan demokrasi yang bersifat

\footnotetext{
${ }^{8}$ Maszlee Malik, "From Political Islam to Democrat Muslim",hlm. 27.

${ }^{9}$ Rached Ghannouchi, "The State and Religion in the Fundamentals of Islam and Contemporary Interpretation," Contemporary Arab Affairs, Vol, 6. No, 2, 2013, hlm. 11

${ }^{10}$ Rached Ghannouchi, "From Political Islam to Muslim Democracy: The Ennahda Party and the Future of Tunisia," Foreign Affairs, Vol. 95, No. 5, 2016, hlm, 22
} 
Volume 16, Nomor 1, Januari - Juni 2021

konsensus. Ghannouchi, melalui Ennahda telah secara konsisten berpegang pada pendekatan semacam itu untuk memastikan bahwa Tunisia pasca revolusi tidak akan didominasi oleh satu kekuatan tunggal, yang akhirnya dapat mengarah kepada kediktatoran.

\section{Islam demokratis perspektif Ghannouchi}

Melihat karya-karya Ghannouchi, maka akan kita temukan istilah Islam Demokratis (al-Dimuqratiyah) didefinisikan tidak secara jelas dan spesifik. Dalam berbagai karya Ghannouchi, khususnya al-Dimuqratiyah wa al-Huquq al-Insan (Demokrasi diantara Hak Asasi Manusia), kita akan mendapati bahwa kata demokrasi adalah salah satu dari sekian banyak istilah yang digunakan. Namun, penggunaan istilah tersebut nampaknya dibiarkan tidak terdefinisi dengan jelas. Terkadang, istilah shura digunakan oleh Ghannouchi setara pengertiannya dengan demokrasi. Ghannouchi, yang notabene adalah seorang filosof, pemikir dan seorang politisi, sepertinya mengabaikan konteks sejarah yang berbeda dari kedua istilah tersebut. Ia nampaknya menggunakan kedua istilah tersebut secara bergantian sebagai sinonim. Al-Rab'i juga mengomentari dalam bukunya al-Islam al-Siyasi wa alHadatsah (Islam dan Modernitas): "aspek yang membingungkan dalam karya-karya alGhannouchi adalah persamaan antara terminologi yang baru dengan yang lama, seolah-olah terminologi itu mempunyai definisi yang sama"11

Meskipun al-Ghannouchi telah lama menggunakan istilah demokrasi dalam karyakaryanya, tapi penggunaan istilah 'Islam Demokratis' baru muncul pada tahun 2014 setelah terjadinya reformulasi konstitusi. Hal itu disebabkan oleh banyaknya ketidak-sepakatan Ghannouchi melalui Ennahda terhadap banyak konsep, terutama konsep Syari'ah. Pemikiran Islam Demokratis perspektif Ghannouchi nampaknya juga menyerupai pemikiran al-Banna yaitu: "seorang pengamat bisa dengan mudah memperhatikan bahwa prinsip-prinsip konstitusional pemerintahan dapat diringkas dalam pemeliharaan kebebasan individu, syura (musyawarah), keputusan dan sanksi, tanggung jawab penguasa kepada rakyat, kejelasan keterbatasan kekuasaan, kesesuaian antara Islam dan kepemerintahan". ${ }^{12}$

\section{Prinsip-prinsip Politik Ghannouchi}

Prinsip-prinsip politik Ghannouchi yang dijalankan oleh partainya En-Nahda sejalan dan merupakan warisan dari ideologi Ikhwanul Muslimin. Prinsip-prinsip tersebut diantaranya adalah al-Syumuliyah (komprehensifitas Islam), al-Ummah al-Islamiyah

\footnotetext{
${ }^{11}$ Azzam S. Tamimi, The Question of Democracy (Oxford University Press, 2001), hlm, 14

12 A. Zaeny, "Hasan Al Banna Dan Strategi Perjuangannya," Al-Adyan: Jurnal Studi Lintas Agama. Vol. 6, No. 2, 2011, hlm, 20
} 
Volume 16, Nomor 1, Januari - Juni 2021

(komunitas muslimin), mabda' al-Syura (dewan konstitusi), dan al-Fikr al-Tanzhimi (Prinsip organisasi).

\section{1. al-Syumuliyah (Komprehensifitas Islam)}

Salah satu prinsip terpenting dalam kelompok Ikhwanul Muslimin adalah alSyumuliyah (Komprehensifitas). Prinsip ini berarti bahwa komprehensifitas Islam harus masuk dalam berbagai aspek kehidupan, juga dalam politik. Dalam konferensi Ikhwanul Muslimin, Hasan al-Banna menyatakan: "Ajaran Islam bersifat komprehensif, dan pada gilirannya gerakan Islam (al-Harakah al-Islamiyah) mampu mengatur berbagai urusan. Mereka hanya berpikir bahwa ajaran Islam hanya sebatas membahas aspek ibadah dan spritual. Namun Islam adalah ideologi dan ibadah, negara dan bangsa, agama dan pemerintahan, spiritual dan jihad". ${ }^{13}$

Ghannouchi melalui Ennahda nya tidak mengubah agenda da'awi (terus mengajak orang menuju Islam yang sempurna) adalah bukti konkrit terhadap prinsip al-Syumuliyah ini. Ia berkeyakinan bahwa komprehensifitas Islam didalam semua aspek kehidupan, termasuk politik. Hasilnya pun sangat signifikan, dimana Ennahda memperoleh kantong suara melalui identitas Islamnya, termasuk praktik-praktik dakwah yang dipraktikkan selama hampir sepuluh tahun. Dunn menyatakan:”Ennahda telah memperoleh kesuksesan yang tak terduga dalam pemilihan umum 2011, dimana hal ini sangat dipengaruhi oleh kemampuan mereka untuk melakukan praktik agama semacam berdakwah di daerah-daerah paling terbelakang di negara tersebut". ${ }^{14}$

\section{Al-Ummah al-Islamiyah (Semangat kesatuan)}

Salah satu prinsip politik utama Ghannouchi melalui Ennahda nya adalah "untuk mempromosikan semangat kesatuan Arab dan Islam, kesadaran akan isu-isu mendasar ummah, sehingga bisa mengakhiri permusuhan dan perpecahan, mewujudkan kesatuan yang komprehensif, sehingga memberikan kepentingan tertinggi bagi persatuan negara-negara Arab". Konsep al-Ummah al-Islamiyah sangat penting dalam pemikiran Ghannouchi. Ia percaya bahwa isu al-Ummah al-Islamiyah secara keseluruhan merupakan interpretasi dari syari'ah. Penamaan sistem negara sebagai khilafah atau negara, presidensial atau parlementer, bukan persoalan yang mendasar bagi Ghannouchi. Yang benar-benar penting baginya adalah peran Islam itu sendiri dalam sebuah negara. Ghannouchi percaya bahwa agar

\footnotetext{
${ }^{13}$ Zaeny, "Hasan Al Banna Dan Strategi Perjuangannya", hlm, 13

${ }^{14}$ Michael Collins Dunn, "The Al-Nahda Movement in Tunisia: From Renaissance to Revolution," in Islamism and Secularism in North Africa, ed. John Ruedy (New York: Palgrave Macmillan US, 1996), hlm, 46
} 
Volume 16, Nomor 1, Januari - Juni 2021

aturan akan berjalan apabila terdapat keadilan, deliberatif, dan memiliki hukum yang berlandaskan al-Quran, al-Sunnah dan Maqasid al-Syari'ah.

Pemikiran politik Ghannouchi ini tidak berbeda jauh seperti pemikiran politik alBanna. Dimana al-Banna percaya bahwa ummat Islam harus membangun kembali kekhalifahan Islam, karena disitu merupakan simbol persatuan umat, dan pada saat yang sama, merupakan kewajiban agama. Dengan demikian, al-Banna menempatkan permasalahan Khilafah dibagian penting dalam pemikiran politiknya. Meskipun, al-Banna mengakui bahwa beberapa langkah awal harus diutamakan, seperti kerjasama budaya dan ekonomi diantara masyarakat muslim, selanjutnya diikuti dengan kerjasama dan perjanjian militer diantara negara-negara muslim tersebut.

\section{Al-Fikr al-Tanzhimi (Struktur Organisasi)}

Ennahda yang dinahkodai oleh Ghannouchi adalah sebuah partai yang besar dan mempunyai struktur organisasi yang kuat. Struktur organisasi partai ini juga mengadopsi dari struktur partainya al-Banna yaitu Ikhwanul Muslimin. Partai ini mempunyai pemimpin, dewan shura, komunitas (al-J ama'ah), dan mempunyai komitmen dan disiplin yang jelas. Hasil dari struktur organisasi yang kuat ini, menjadikan Ennahda sebagai Partai Politik yang memenangkan suara terbesar dalam pemilu yang diadakan secara jujur, adil dan demokratis setelah tumbangnya rezim Ben Ali di Tunisia.

Hierarki kekuasaan yang jelas juga terlihat dalam partainya Ghannouchi hari ini, dimana Ghannouchi sendiri sekarang menjabat sebagai Ketua Dewan Perwakilan Rakyat Tunisia. Komitmen dan disiplin yang jelas dalam tubuh partai ini, membuat semua anggotanya menerima dan tunduk pada keputusan yang telah dibuat. Tanpa ada upaya untuk membuat konsolidasi internal untuk menjatuhkan Ghannouchi.

Ghannouchi berpendapat bahwa sistem demokrasi adalah akibat dari pengalaman negara-negara Barat khususnya. Ia sendiri menerima demokrasi menjadi salah satu metode pemerintahan. Dalam pandangannya, masalah umat Islam bukan terletak pada model demokrasi itu sendiri, tetapi lebih kepada nilai-nilai sekulerisme yang ada di belakang orangorang yang menyuarakan demokrasi. Berangkat dari hal tersebut, muncullah istilah Islam Demokratis. ${ }^{15}$ Islam Demokratis akan menjadikan sistem demokrasi akan berubah melalui nilai-nilai moral yang bersumber dari al-Quran dan al-Sunnah. Gagasan ini, meskipun sedikit kontroversial, telah mendapat banyak perhatian oleh pemikir Islam dan membuat Ghannouchi terkenal dikalangan gerakan Islam kontemporer.

Secara umum, Rachid Ghannouchi tidak secara khusus membahas konsep Islam Demokratis. Wacana Islam Demokratis perspektif Ghannouchi ini dapat kita lihat secara

\footnotetext{
${ }^{15}$ Ghannouchi, "From Political Islam to Muslim Democracy." hlm, 33
} 
Volume 16, Nomor 1, Januari - Juni 2021

tidak langsung melalui karya, wawancara, dan ceramahnya, termasuk makalah dan tulisan yang meneliti pemikirannya. Ghannouchi menyatakan bahwa masalah perpolitikan merupakan salah satu ladang ijtihad. Politik yang dalam Islam dikenal dengan sebutan alSiyasah, merupakan salah satu hal yang pintu ijtihadnya masih terbuka lebar. Berbagai keputusan terkait al-Siyasah harus dibuat berdasarkan kepentingan dan situasi saat ini. Oleh karena itu, konsep Islam Demokratis menurutnya berada dalam ruang ijtihad yang masih terbuka lebar untuk didiskusikan.

Islam demokratis perspektif Ghannouchi tidak berarti mengesampingkan Islam sebagai bentuk negara yang ideal dan model bagi pemerintahan dan administrasi. Menurutnya, konsep Islam Demokratis juga tidak melarang implementasi sistem syari'ah dalam pemerintahan sebagai suatu sistem yang komprehensif, menjamin keharmonisan, dan menjunjung tinggi nilai-nilai kemanusiaan. Ghannouchi juga menekankan bahwa Islam Demokratis memiliki karakteristik untuk menjamin persamaan hak tehadap Hak Asasi Manusia, kebebasan untuk mengeluarkan pendapat, kemerdekaan berpikir dan kebebasan dalam memilih keyakinan.

Ghannouchi sendiri sangat realistis dan tidak terburu-buru dengan ide mendirikan negara Islam, atau untuk mengembalikan kejayaan khilafah pada masa sekarang ini. Ia lebih memilih untuk melakukan pendekatan secara bertahap, mempertimbangkan berbagai masukan dan aspirasi dari grassrout masyarakat dalam mengimplementasikan berbagai ide dan perubahan. Ghannouchi berkeyakinan bahwa konteks berbangsa dan bernegara akan mengalami kemajuan signifikan dengan memastikan persatuan dan pembangunan nasional. Untuk mewujudkan persatuan bangsa yang kuat, ia melihat bahwa aspek politik, budaya. Pendidikan dan pemberdayaan ekonomi sebagai kepentingan publik yang harus diprioritaskan. Secara umum, konsep Islam Demokratis perspektif Ghannouchi mengacu pada konsep sebuah negara yang menggabungkan elemen demokrasi, syura, kebebasan, Hak Asasi Manusia, budaya dan identitas.

Ghannouchi memandang bahwa demokrasi yang mengutamakan Hak Asasi Manusia, kebebasan dan keadilan sama sekali tidak bertentangan dengan hukum Islam, bahkan dinilai sejalan dengan tuntunan maqashid al-syari' ah.

Pemikiran Rachid Ghannouchi yang berkaitan dengan politik terbagi dalam 2 (dua) bagian; Pertama, Reformasi sosial dengan asas akidah, Kedua, Demokrasi Islam. Pemikiran Ghannouchi menjadi titik kulminasi penting dalam pemikiran politik Islam modern, sebagaimana ditelaah Andrew F. March dalam The Caliphate of Man: Popular Sovereignty in Modern Islamic Thought. March menelusuri janji primordial yang ditekankan Ghannouchi itu dalam demokrasi Islam diubah menjadi kedaulatan populer yang menerjemahkan khalifatullah melalui kepemilikan akal (untuk pemikiran), kehendak (hati nurani), dan 
Volume 16, Nomor 1, Januari - Juni 2021

kebebasan (ekspresi). Ketiga hal ini adalah pemberian Tuhan yang paling mendasar kepada manusia sebagai khalifah-Nya. ${ }^{16}$

Dari situ, Ghannouchi menyatakan segala konsep hak asasi manusia dan kesejahteraan manusia harus beralih dari konsepsi sekuler Barat ke arah yang lebih Islami, yakni mengacu pada fitrah kemanusiaan sebagai anugerah Tuhan. Selain tak mengikuti genealogi Barat, konsep khilafah universal dalam pemikirannya keluar dari mainstream pemikiran politik Islam modern Salafiyyah dan kekhalifahan internasional yang utopis.

Bagi Ghannouchi, Islam dan demokrasi menjadi pelengkap satu sama lain. Hanya dengan Islam, argumennya, demokrasi akan menemukan energi hebat dalam mewujudkan berbagai kebutuhan mendasar umat manusia, yakni material, spiritual, individual, dan sosial. Segala syarat dan prinsip demokrasi diterima dengan penekanan pada teori konstitusional Islam yang menempatkan kedaulatan rakyat sebagai yang tertingi dengan konstitusi sebagai sumber hukum bersama.

\section{Islam dan Negara: Sebuah Relasi}

Penafsiran tentang relasi antara Islam dan negara dikalangan umat Islam dewasa ini terbagi menjadi tiga aliran. Pertama, aliran yang meyakini bahwasanya Islam bukan sematamata agama yang hanya menyangkut hubungan manusia dan Tuhan, sebaliknya Islam adalah suatu agama yang sempurna dan komprehensif yang mengatur seluruh aspek kehidupan manusia termasuk kehidupan politik. Kelompok ini berargumen bahwa: (1) Islam adalah agama yang komprehensif dan lengkap. Didalamnya terdapat pula sistem ketatanegaraan atau politik. (2)Ketatanegaraan Islam adalah sistem yang telah dilaksanakan oleh Nabi Muhammad Saw, dan empat al-Khulafa' al-Rasyidin. Tokoh utama dari pemikiran ini antara lain adalah Hasan al-Banna, Sayyid Qutb, Muhammad Rasyid Ridha dan al-Maududi. ${ }^{17}$ Kelompok ini sering disebut dengan aliran tradisionalis. Di Indonesia model pemikiran ini dipegang oleh M. Rasyidi, M. Natsir, Abikusno Tjokrosoejoso dan A. Wahid Hasyim. Dalam konteks ke-Indonesiaan, aliran ini telah lama muncul, bahkan pra kemerdekaan Indonesia. Tahun tiga puluhan misalnya, Muhammad Natsir yang disebut Bahtiar sebagai penggagas ide ini, banyak terlibat dalam diskusi dan debat panjang dengan Soekarno mengenai hal ini. ${ }^{18}$

\footnotetext{
${ }^{16}$ Andrew F. March, The Caliphate of Man: Popular Sovereignty in Modern Islamic Thought (USA: Harvard University Press, 2019), hlm, 28

17 Zainun Kamal et al., eds., Islam, Negara \& Civil Society: Gerakan Dan Pemikiran Islam Kontemporer, Cet. 1 (Jakarta: Paramadina, 2005), hlm, 32

${ }^{18}$ Bahtiar Effendy, Islam and the State in Indonesia, Ohio University Research in International Studies. Southeast Asia Series (Athens: Singapore: Ohio University Press ; Institute of Southeast Asian Studies, 2003), hlm, 44
} 
Volume 16, Nomor 1, Januari - Juni 2021

Maududi sendiri berpendapat bahwa kebutuhan akan terciptanya negara Islam adalam sebuah sunnatullah, "hal ini merupakan bagian dari ideologi yang luas tapi terintegrasi, yaitu prinsip kedaulatan Tuhan sang Pencipta Alam". ${ }^{19}$ Klimaksnya, aliran ini menolak keras terhadap pandangan yang memisahkan antara Negara dan agama. Maududi sendiri berpendapat bahwa raison d' etre Negara Islam adalah untuk mentaukidkan kedaulatan Tuhan di muka bumi ini.

Aliran yang kedua, adalah aliran yang memiliki corak pendapat bahwa Islam merupakan agama yang hanya mengajarkan tentang relasi Tuhan dan hamba, dan tentang kehidupan akhirat semata. Sama sekali dalam ajaran Islam tidak didapati tentang suatu perintah atau ketentuan yang berbicara mengenai aturan politik dan ketatanegaraan. Tokoh utama pemahaman ini adalah 'Ali 'Abd al-Raziq. Pemikirannya tentang khilafah dan ketatanegaraan tertuang pada karyanya yang berjudul al-Islam wa Ushul al-Hukm yang sempat membuat keresahan ditengah masyarakat Mesir. Dalam karyanya tersebut, 'Ali 'Abd al-Raziq meyakini dan berpegang teguh bahwa tidak terdapat satu nash pun dalam al-Quran dan al-Hadist yang memerintahkan Rasulullah untuk membentuk suatu sistem ketatanegaraan ataupun kerajaan. ${ }^{20}$

Menurut al-Raziq, syariat Islam semata-mata hanya bercorak spritual, sama sekali tidak memiliki hubungan dengan praktik duniawi, bahkan Islam tidak mempunyai keterikatan apapun dengan pemerintahan dan ketatanegaraan. Pemikiran al-Raziq ini mendapat dukungan dari Abdullah Ahmed an-Naim, seorang pemikir muslim kontemporer kelahiran Sudan. Bahkan, an-Na'im mendetailkan gagasan al-Raziq secara spesifik. Ia menegaskan bahwa periode Islam mulai dari Nabi Muhammad, Khalifah al-Rasyidin, Dinasti Umayyah, Dinasti Abbasiyah, hingga Dinasti Utsmaniyyah, semua mengacu pada ketatanegaraan yang sekuler.

Di Indonesia, tokoh dan cendekiawan muslim yang condong kepada aliran ini diantaranya; Nurcholis Madjid, Abdurrahman Wahid, Harun Nasution dan Munawir Sjadzali. Cak Nur sendiri meyakini bahwa negara adalah salah satu segi kehidupan duniawi yang dimensinya adalah rasional dan kolektif. Bertolak belakang dengan agama yang merupakan aspek kehidupan yang dimensinya berlainan dan berlandaskan spritual dan personil. Agama dan negara memang tidak mungkin dipisahkan, namun antara agama dan Negara harus dibedakan, baik dari dimensinya maupun dari cara pendekatannya. ${ }^{21}$

\footnotetext{
${ }^{19}$ Sayyid Abul A'la Maududi, "The Political Theory of Islam," in Modernist and Fundamentalist Debates in Islam: A Reader, ed. Mansoor Moaddel and Kamran Talattof (New York: Palgrave Macmillan US, 2000), hlm, 57

${ }^{20}$ Syahrudin Siregar, "Khilafah Islam Dalam Perspektif Sejarah Pemikiran Ali Abdul Raziq," JUSPI (Jurnal Sejarah Peradaban Islam), Vol. 2, No. 1, 2018, hlm, 32

${ }^{21}$ Masykuri Abdillah, "Hubungan Agama Dan Negara Dalam Konteks Modernisasi Politik Di Era Reformasi," AHKAM : Jurnal Ilmu Syariah, Vol. 13, No. 2, 2013, hlm.14
} 
Volume 16, Nomor 1, Januari - Juni 2021

Aliran yang ketiga, adalah aliran yang menolak pendapat bahwa Islam merupakan suatu agama yang kaffah (lengkap), bahkan mengenai sistem ketatanegaraan dan pemerintahan. Aliran ini juga tidak sependapat dengan anggapan bahwa Islam adalah agama yang semata mengatur hubungan manusia dan Tuhan. Kelompok ini meyakini bahwa dalam Islam tidak dijelaskan tentang ketatanegaraan dan pemerintahan secara spesifik, tetapi hanya terdapat seperangkat etika bagi kehidupan bernegara. Tokoh yang menonjol dalam pemikiran ini adalah Fachruddin dan Muhammad Husein Haikal. Kelompok ini terkenal dengan kelompok modernis. Haikal meyakini bahwa Islam bukanlah sebuah agama yang mengatur setiap sisi kehidupan, tetapi tidak berarti bahwa Islam hanyalah agama yang mementingkan ritual semata dan mengesampingkan urusan-urusan duniawi. ${ }^{22}$

Senada dengan Haikal, Fachruddin berpendapat bahwa aliran ini meyakini bahwa demokrasi tidak sejalan dengan Islam, hal ini dikarenakan demokrasi semata-mata hanya menekankan tentang kedaulatan manusia. Konsep ini menurut mereka tidak kompatibel dengan prinsip Islam yang mengakui konsep hakimiyat (حكمية) atau kedaulatan Tuhan.

Ghannouchi sendiri disinyalir awalnya terpengaruh dengan pemahaman Sayyid Qutb dan Maududi, pandangan tersebut berubah saat mempelajari pemikiran Malik Bennabi, antitesis dari pemikiran Sayyid Qutb. Kritikan pedas Bennabi terhadap Qutb, terutama terkait tentang peradaban. Menurutnya, peradaban adalah transformasi ide yang baik dan menjadi kenyataan. Beragam pemikiran yang dipelajari Ghannouchi dan dinamika sosio-politik di negara-negara Arab turut mengubah jalan pikirannya. Ghannouchi tidak lagi terbelenggu dengan doktrin Islamisme ala Sayyid Qutb, Maududi, Hasan al-Banna dan Bennabi. Ghannouchi merangkai semua pemikiran itu menjadi cara pandang progresif dalam melihat realitas politik dan negara.

Cara pandang progresif yang dimaksud adalah, ketika Ghannouchi, pemimpin partai En-Nahda yang berhaluan Islam, mendapat mandat rakyat memegang kendali pemerintahan pasca revolusi Yasmin. Ghannouchi sendiri tidak mengubah haluan negara menjadi haluan Islam, namun mempertimbangkan demokrasi sebagai harapan rakyat dan Islam sebagai identitas. Keduanya dapat berjalan harmonis mewujudkan kemakmuran, kesetaraan, dan tentunya kebebasan.

Pemikiran Ghannouchi mencerminkan pemahaman yang luar biasa tentang falsafah Barat dan Islam dan keprihatinan tulen untuk mendamaikan prinsip asas Islam dengan kemodernan dan kemajuan. Ghannouchi menilai Barat dalam dimensi falsafah dialog TimurBarat. Beliau melihat Barat sebagai pengimbang ideologi kepada doktrin Islam, Barat dianggap tidak lebih tinggi atau lebih rendah dengan Islam. Ghannouchi melihat kewujudan

\footnotetext{
${ }^{22}$ Arsyad Sobby Kesuma, "Islam Dan Politik Pemerintahan (Pemikiran Politik Muhammad Husein Haikal)," Analisis: Jurnal Studi Keislaman, Vol. 13, No. 2, 2013, hlm, 14
} 
Volume 16, Nomor 1, Januari - Juni 2021

bersama dan kerjasama sebagai asas hubungan antara kedua-duanya. Penetapan kedua prinsip ini adalah perbedaan dalam persepsi mereka terhadap konsep-konsep asas, atau "ide-ide efektif", yang menggerakkan budaya mereka: nilai dan kedudukan kemanusiaan di alam semesta.

\section{Islam dan Demokrasi}

Besarnya nilai Islam yang dihadirkan dalam berbagai gerakan atas nama sosial menghadirkan pertanyaan tentang masa depan demokrasi yang dibawa oleh masyarakat sipil diberbagai penjuru dunia. Samuel P. Huntington beragumen bahwa, agama terutama Islam, memberikan batasan pada demokrasi. Pada tahun 1993, sejarawan Timur Tengah Lewis berusaha menjawab berbagai pertanyaan mengenai Islam dan demokrasi liberal. Dia mempertanyakan, dapatkah demokrasi bekerja dalam masyarakat yang terinspirasi oleh kepercayaan, pengalaman, serta tradisi Islam? Penelitiannya menawarkan beberapa kesimpulan bahwa prospek bagi demokrasi di Timur Tengah tidaklah baik, dan ketika ditinjau dari perspektif politik, Islam menawarkan prospek terburuk terhadap demokrasi liberal. ${ }^{23}$

Situasi ini sering menjadi klaim bahwa Islam tidaklah selaras dengan demokrasi dan tidak memiliki prospek dalam menerapkan demokrasi. Akan tetapi, konklusi dan kesimpulan para ahli tersebut tampaknya tidak benar jika kita menelisik perjalanan demokrasi di berbagai negara, termasuk Indonesia yang merupakan negara mayoritas muslim terbesar didunia. Keberhasilan pelaksanaan tahapan Pemilu pada 2004, 2009, 2014, dan 2019 di Indonesia secara aman dan damai menjadi bukti dan anti-tesis dari pemikiran para ahli tersebut. Demokrasi dapat berjalan dan dipraktikkan di tengah masyarakat muslim mayoritas. Indonesia turut mempelopori relasi demokrasi dan Islam dalam sistem perpolitikan, hal ini terbukti dengan munculnya partai-partai Islam yang mendukung demokrasi seperti PKS, PPP, PKB dan PAN. ${ }^{24}$

Konsep demokrasi tidaklah semata-mata konsep yang mudah dicerna, sebab konsep ini memiliki berbagai konotasi makna yang dinamis dan evolutif. Dengan makna-maknanya ini, setiap penguasa suatu negara berhak untuk mengklaim negaranya sebagai negara yang demokratis, meskipun prinsip yang dianut dalam praktik kekuasaan yang ditampilkan jauh dari etika dasar demokrasi. Karena sifatnya yang dinamis ini, kita mengenal berbagai tipologi demokrasi seperti demokrasi liberal, demokrasi rakyat, demokrasi terpimpin, demokrasi pancasila, demokrasi parlementer dan lain sebagainya.

\footnotetext{
${ }^{23}$ Bradley J. Cook and Michael Stathis, "Democracy and Islam: Promises and Perils for the Arab Spring Protests," Journal of Global Responsibility, Vol. 3, No. 2, 2012, hlm, 12

${ }^{24}$ Gonda Yumitro, "Partai Islam Dalam Dinamika Demokrasi Di Indonesia," Jurnal Ilmu Sosial Dan Ilmu Politik, Vol. 17, No. 1, 2013, hlm, 44
} 
Volume 16, Nomor 1, Januari - Juni 2021

Banyak ilmuwan muslim baik yang klasik maupun kontemporer meyakini bahwa dalam demokrasi terdapat nilai-nilai Islami yang menguatkan konsep demokrasi itu sendiri. Diantara nilai-nilai tersebut adalah:

\section{Konsep Shura ( )}

Diskusi antara relasi hubungan Islam dan politik, konsep shura merupakan suatu konsep yang fundamental. Isu shura mempunyai kedudukan yang urgen, tidak hanya dikalangan komunitas muslim saja, tetapi juga telah dikenal pada komunitas global. Di Asia Tenggara sendiri, konsep shura ini banyak diadopsi oleh partai-partai politik Islam semisal Partai Keadilan Sejahtera (PKS) di Indonesia dan Partai Islam se-Malaysia (PAS) di Malaysia. Kedua partai ini menjadikan majelis shura sebagai pemegang keputusan serta pengambil kebijakan tertinggi didalam partai tersebut.

Ilmuwan muslim sepakat bahwa konsep shura merupakan hal terpenting dalam kehidupan politik. Kewajiban untuk bermusyawarah merupakan hal wajib yang diharus dilakukan oleh pemegang kekuasaan terhadap masalah yang berkaitan dengan kebijakan dan kepentingan publik. Konsep shura ini juga telah dilakukan oleh para khulafaurrasyidin semisal Abu Bakar yang telah membentuk Majelis Shura dimasa kepemimpinannya, yang terdiri dari perwakilan kaum muhajirin dan anshar dalam mengambil keputusan dan kebijakan. ${ }^{25}$

Hal senada juga terjadi pada masa kekhalifahan dipegang oleh Umar bin Khattab yang membentuk Majelis Shura yang berkomposisikan enam sahabat utama Nabi diakhir-akhir kekuasaannya. Majelis Shura ini bertugas untuk melaksanakan fit and propert test terhadap sahabat-sahabat utama yang akan ditunjuk untuk menggantikan posisi Umar sebagai khalifah. Dengan pembentukan Majelis Shu|ra ini, tergambar secara utuh bahwa Umar diakhir-akhir kepemimpinannya membiarkan proses pemilihan khalifah penggantinya secara terbuka dan diwewenangkan sepenuhnya kepada 'komite enam' tersebut. Sebagaimana kita ketahui, bahwa komunitas muslim di Madinah saat itu berhasil mengerucutkan nama calon pengganti Khalifah Umar bin Khattab menjadi dua orang yaitu Utsman bin Affan dan Ali bin Abi Thalib.

Dengan adanya konsep shura ini, ilmuwan muslim semisal Rachid al-Ghannouchi, Fazlur Rahman, Yusuf al-Qaradhawi, Said Ramadhan al-Buthi meyakini bahwa Islam kompatibel dengan demokrasi. Di Indonesia diwakili oleh Nurcholis Madjid, Amin Rais, Munawir Syadzali, dan Ahmad Sjafi'i Ma'arif.

\footnotetext{
${ }^{25}$ Kun Budianto, "Kelembagaan Politik Islam: Konsep Konstitusi, Legislasi, Demokrasi, Ummah Dan Syura,," Jurnal Studi Sosial Dan Politik, Vol, 1. No. 2, 2017, hlm.13
} 
Volume 16, Nomor 1, Januari - Juni 2021

Dalam kajian politik Islam kontemporer, shura sering dihubungkan dengan demokrasi. Secara umum, ada pendapat yang saling berbeda mengenai kompabilitas shu|ra dan demokrasi. Pendapat pertama, menyatakan bahwa pada hakikatnya demokrasi itu sama dan tidak bertentangan dengan prinsip shura. Pendapat kedua, menyatakan bahwa demokrasi yang berasal dari konsep barat yang sangat kurang penekanannya terhadap aspek spritual tidaklah bersesuaian dengan shura yang amat sarat dengan muatan spritual. Pendapat ketiga, menyatakan persamaan antara shura dan demokrasi hanyalah pada sebagian hakikatnya. Karena itu, pendapat yang tepat adalah bahwa shura dan demokrasi itu tidak serupa, tetapi memiliki kesamaan secara prinsip.

\section{Konsep Kebebasan (حرية)}

Salah satu syarat terwujudnya demokrasi adalah adanya kebebasan, walaupun tidak semua bentuk kebebasan menunjukkan makna demokrasi. Menurut Ghannouchi sendiri, kebebasan (حرية) sendiri hanya mencakup pada kebebasan politik yang bersinergi dengan kebebasan bersuara, berpartisipasi dalam politik, dan mempengaruhi pemerintah. Sebuah sistem yang demokratis harus memberikan pengakuan atas kebebasan masyarakat untuk berkumpul, mengkomunikasikan ide dari satu ke yang lain. Dalam islam sendiri, kebebasan ini meliputi kebebasan beragama dan kebebasan berpikir. Kebebasan beragama adalah kebebasan paling fundamental dalam urusan sosio-politik kehidupan manusia. Kebebasan berpikir juga merupakan media utama untuk dapat membentuk tatanan kehidupan yang seusai dengan waktu, tempat dan masa.

Prinsip kebebasan (حرية) dalam Islam disebut berulang kali dalam al-Quran dalam berbagai konteks. Dalam konteks kebebasan beragama sendiri, terdapat banyak ayat al-Quran yang tidak memaksakan orang dalam memeluk dan menganut Islam seperti QS. Al-Baqarah ayat 256, al-Kahfi ayat 29, dan surat al-Ghasyiyah ayat 21-22. Dari ayat-ayat tersebut, dapat kita pahami bahwa prinsip kebebasan (حرية) adalah prinsip yang fundamental yang harus dilaksanakan untuk menciptakan demokrasi yang kompatibel dengan Islam.

\section{Penutup}

Rachid Ghannouchi adalah sosok inspiratif yang berpikir jauh kedepan. Gagasangagasannya membawa Islam yang substantif diterima rakyat sebagai kanal pelepasan menuju era baru demokratisasi yang sebenarnya. Ide pokok pemikiran Ghannouchi pada dasarnya adalah berusaha untuk mencari titik temu antara Islam, demokrasi, nasionalise dan kesejahteraan. Transformasi pemikiran Ghannouchi dari seorang anak didik al-Albani menjadi seorang Muslim-Demokrat yang berani bereksperimen dengan memadukan antara Islamisme dengan nasionalisme, demokrasi bahkan sekularisme, menjadikan ide dan gagasannya mulai dipraktikkan di berbagai belahan dunia. Rachid Ghannouchi telah memberikan pandangan baru bagi Negara Tunisia secara khusus dan dunia Islam pada 
Lurnas Fukum

Samudra Keadilan

Volume 16, Nomor 1, Januari - Juni 2021
P-ISSN : $\quad 2615-3416$

E-ISSN : $\quad 2615-7845$

umumnya terhadap pergerakan politik demokrasi yang dipadukan dengan konsep Islam dengan mengedepankan konsep kebebasan dan shura dalam berpolitik.

\section{DAFTAR PUSTAKA}

Abdillah, Masykuri. "Hubungan Agama Dan Negara Dalam Konteks Modernisasi Politik Di Era Reformasi." AHKAM : Jurnal Ilmu Syariah 13, no. 2 (August 7, 2013): 14. https://doi.org/10.15408/ajis.v13i2.937.

Abrams, Elliott. Realism and Democracy: American Foreign Policy after the Arab Spring. New York: Cambridge University Press, 2017.

Budianto, Kun. "Kelembagaan Politik Islam: Konsep Konstitusi, Legislasi, Demokrasi, Ummah Dan Syura'." Jurnal Studi Sosial Dan Politik 1, no. 2 (December 30, 2017): 13. https://doi.org/10.19109/jssp.v1i2.4040.

Cook, Bradley J., and Michael Stathis. "Democracy and Islam: Promises and Perils for the Arab Spring Protests." Journal of Global Responsibility 3, no. 2 (January 1, 2012): 12. https://doi.org/10.1108/20412561211260485.

Dunn, Michael Collins. "The Al-Nahda Movement in Tunisia: From Renaissance to Revolution." In Islamism and Secularism in North Africa, edited by John Ruedy, 46. New York: Palgrave Macmillan US, 1996. https://doi.org/10.1007/978-1-349-613731_9.

Effendy, Bahtiar. Islam and the State in Indonesia. Ohio University Research in International Studies. Southeast Asia Series. Athens : Singapore: Ohio University Press ; Institute of Southeast Asian Studies, 2003.

Ghannouchi, Rached. "From Political Islam to Muslim Democracy: The Ennahda Party and the Future of Tunisia." Foreign Affairs, 2016.

. "From Political Islam to Muslim Democracy: The Ennahda Party and the Future of Tunisia." Foreign Affairs 95, no. 5 (2016): 33.

- "The State and Religion in the Fundamentals of Islam and Contemporary Interpretation." Contemporary Arab Affairs, 2013. https://doi.org/10.1080/17550912.2013.783184.

Hakiki, Kiki Muhamad. "Islam dan Demokrasi: Pandangan Intelektual Muslim dan Penerapannya di Indonesia." Wawasan: Jurnal Ilmiah Agama dan Sosial Budaya 1, no. 1 (February 1, 2016): 1-17. https://doi.org/10.15575/jw.v1i1.583. 
Volume 16, Nomor 1, Januari - Juni 2021

Ibn- Asur, Mu ammad a - āhir. Treatise on Maqāșid Al-Shari ah. London: Internat. Inst. of Islamic Thought, 2006.

Kamal, Zainun, Komaruddin Hidayat, Ahmad Gaus A. F, and Munawir Sjadzali, eds. Islam, Negara \& Civil Society: Gerakan Dan Pemikiran Islam Kontemporer. Cet. 1. Jakarta: Paramadina, 2005.

Kesuma, Arsyad Sobby. "Islam Dan Politik Pemerintahan (Pemikiran Politik Muhammad Husein Haikal).” Analisis: Jurnal Studi Keislaman 13, no. 2 (2013): 14. https://doi.org/10.24042/ajsk.v13i2.703.

Malik, Maszlee. "From Political Islam to Democrat Muslim: A Case Study of Rashid Ghannouchi's Influence on ABIM, IKRAM, AMANAH and DAP." Intellectual Discourse, 2017.

March, Andrew F. The Caliphate of Man: Popular Sovereignty in Modern Islamic Thought. USA: Harvard University Press, 2019. https://doi.org/10.2307/j.ctvp2n3ms.

Maududi, Sayyid Abul A'la. "The Political Theory of Islam." In Modernist and Fundamentalist Debates in Islam: A Reader, edited by Mansoor Moaddel and Kamran Talattof, 57. New York: Palgrave Macmillan US, 2000. https://doi.org/10.1007/978-1-137-09848-1_25.

Rukajat, Ajat. Pendekatan Penelitian Kualitatif (Qualitative Research Approach). Yogyakarta: Deepublish, 2018.

Siregar, Syahrudin. "Khilafah Islam Dalam Perspektif Sejarah Pemikiran Ali Abdul Raziq." JUSPI (Jurnal Sejarah Peradaban Islam) 2, no. 1 (July 31, 2018): 32. https://doi.org/10.30829/j.v2i1.1794.

Tamimi, Azzam S. The Question of Democracy. Oxford University Press, 2001. https://doi.org/10.1093/0195140001.001.0001.

Yom, Sean. "The Arab Spring: One Region, Several Puzzles, and Many Explanations." Government and Opposition, 2015. https://doi.org/10.1017/gov.2015.19.

Yumitro, Gonda. "Partai Islam Dalam Dinamika Demokrasi Di Indonesia." Jurnal Ilmu Sosial Dan Ilmu Politik 17, no. 1 (2013): 35-50. https://doi.org/10.22146/jsp.10892.

Zaeny, A. "Hasan Al Banna Dan Strategi Perjuangannya." Al-Adyan: Jurnal Studi Lintas Agama 6, no. 2 (December 31, 2011): 20. https://doi.org/10.24042/ajsla.v6i2.500.

Zed, Mestika. Metode Peneletian Kepustakaan. Jakarta: Yayasan Obor Indonesia, 2004. 